\title{
Influence of aquatic plant architecture on epiphyte biomass on a tropical river floodplain
}

\author{
N. E. Pettit ${ }^{1}$, D. P. Ward², M. F. Adame' ${ }^{2}$, D. Valdez² and S.E. Bunn². \\ ${ }^{1}$ Centre of Excellence in Natural Resource Management, The University of Western Australia, \\ Albany, Western Australia. . \\ ${ }^{2}$ Australian Rivers Institute, Griffith University, 170 Kessels Rd, Nathan, Queensland, \\ Australia \\ *Current Address: School of Natural Sciences, Edith Cowan University, Western Australia.
}

\begin{abstract}
Tropical floodplains are highly productive because of seasonal replenishment of water and nutrients, which substantially boost primary productivity. This study examined how the architecture of aquatic macrophytes affect the light and water quality and consequently the attachment and biomass of epiphytes on a floodplain in northern Australia. Results show that macrophyte structural complexity is not only important for water column light penetration but also for the development of epiphytes on macrophytes. Emergent grasses with simple vertical structure and high plant densities, limit light penetration and consequently the development and biomass of epiphytic algae. In contrast, submerged macrophytes growing just below the water surface, allow greater light penetration. The complex architecture of submerged macrophytes also provides a large surface area for the development of a dense covering of epiphytic algae. Other plant structural forms (e.g., plants with floating leaves) have a simple structure, variable light penetration and low epiphytic algae biomass. The emergent grass Psuedoraphis spinescens (R.Br.) Vickery also had low light penetration but the horizontal alignment of stems across the water surface allow greater exposure to sunlight of the stems and the consequent development of epiphytic algae. We conclude that (1) the complex structure of submerged plants effectively creates a "false bottom" in deeper waters so that they function similarly to the floodplain's littoral zone, and (2) that their extremely large surface area for attachment allows greater production of epiphytic algae than would occur on the sediment surface.
\end{abstract}

Keywords: epiphytic algae, aquatic macrophytes, growth form, light attenuation, PAR, inundation. 


\section{Introduction}

Tropical floodplains are highly productive because seasonal flooding results in the recurrent deposition of nutrient rich sediments (McClain and Richey, 1996, Junk and Wantzen, 2004). Flooding replenishes water on the floodplain, and substantially boosts primary (Junk and Piedade, 1997, Davies et al., 2008) as well as secondary production (Winemiller, 2004). Long inundation periods allow growth of aquatic macrophytes and algae (Junk and Piedade, 1997; Finlayson, 2005; Pettit et al., 2011), and also provide an opportunity for fish to move from the river channel or estuary onto the floodplain where they consume food sources needed for growth (Winemiller, 2004; Jardine et al., 2012). The most conspicuous contributors to tropical floodplain primary production are macrophytes (Piedade et al., 1991; Silva et al., 2009; Pettit et al., 2011). However in terms of secondary production, several investigations in tropical floodplain systems in South America and Australia have found that algae and in particular periphyton (attached microalgae), despite forming an inconspicuous component of the total carbon biomass, provides the source material for the bulk of animal consumer biomass, with macrophytes and terrestrial carbon sources playing only a minor role (Hamilton et al., 1992; Lewis et al., 2001; Jardine et al., 2012). Therefore production of algae on the floodplain in the wet season is a very important component of the floodplain ecosystem (Jardine et al., 2012).

On the inundated floodplain, algal production can take place within the water column (phytoplankton) or as periphyton on substrates such as floodplain sediments (episammic) or hard surfaces (epilithic, epixylic) or attached to plants (epiphytic). Production of algae on the floodplain depends to a large extent on sufficient nutrients and light penetration (photic 
zone) to allow photosynthesis to take place. Macrophytes growing on the floodplain provide a convenient and useful substrate for attachment and growth of periphyton and these macrophytes have various structural forms including emergent, floating and submerged plants with varying morphologies. The structural complexity of these macrophytes types will influence periphyton attachment, with more complex shapes likely to allow greater light penetration through the water column for algae to utilise (Adams et al., 1974) and provide greater surface area for attachment (Warfe and Burmuta, 2006; Hinojosa-Garro et al., 2010). As well as the structural complexity of forms, the alignment of these macrophytes in terms of the degree to which stems are in a vertical or horizontal plane, will also influence the level of exposure of stems to sunlight. Light attenuation has obvious implications for competition within aquatic plants as well as for the growth of epiphytic algae. The littoral zone at the edge of floodplain inundation is an area with high light penetration and available nutrients (Keizer et al., 2014) and therefore where the vast majority of benthic primary production is likely to take place (Strayer \& Findlay, 2010). Aquatic plants growing near the water surface can, however, significantly increase the area available within the photic zone for the growth of attached epiphytic algae in deeper water. This access to light is likely to make macrophyte structure more important than biomass or surface area for the development of epiphytic algae (Jones et al., 2000). This study will investigate the relationship between the photic zone, macrophyte structure and alignment to the biomass of attached epiphytic algae within the flooded floodplain.

The relationship between aquatic macrophytes and epiphytic algae is generally considered in terms of importance as food and habitat. Plant stems and leaves provide a substrate for the attachment of epiphytes for grazing macroinvertebrates and small fish and protection 
from predation (Carpenter and Lodge, 1986). Epiphytes benefit macrophytes by diverting grazers and macrophytes benefit epiphytes by providing a substrate and nutrients (Hutchinson, 1975). High structural complexity of macrophytes are also likely to support the greatest abundance and diversity of macroinvertebrates, and by creating greater surface area and better access to light, the greatest epiphytic algae biomass (Warfe and Barmuta, 2006; Dibble and Thomaz, 2006). Our objective was to understand how the architecture and alignment of aquatic macrophytes affect the light and water environments and consequently the attachment and biomass of epiphytic algae on the Magela Creek floodplain in tropical northern Australia.

\section{Methods}

Study site

Magela Creek is a tributary of the East Alligator River, within Kakadu National Park, Northern Territory, Australia. Bounded by van Diemen Gulf and the Arafura Sea to the north and the sandstone plateau of western Arnhem Land to the south (Lat. $12.428050^{\circ} \mathrm{S}$; Long. $\left.132.869460^{\circ} \mathrm{E}\right)$. The creek flows down from the plateau, across the lowland coastal plains, and distributes water into an expansive clay-based floodplain of $200 \mathrm{~km}^{2}$ (Hart et al., 1987). The region is characterised by a monsoonal climate with distinct wet and dry seasons. The wet season hydro-period of flooded floodplain lasts around 3-5 months (usually November to March); however, this can vary greatly from year to year (Finlayson et al., 1990; Ward et al., 2014). Annual rainfall ( 1300-1500 mm) is mostly from 
thunderstorms, tropical cyclones and monsoonal depressions (Gentilli, 1972; Finlayson, 2005). Following wet season rains, the Magela Creek floods and freshwater spreads over the floodplains, generating the rapid production of aquatic plants and animals. During the dry season the water gradually recedes into rivers, creeks and isolated waterholes, the grassland communities dieback and large patches are frequently burnt (Whitehead and McGuffog, 1997), as fire is used as a management tool to maintain health and diversity on the floodplains of Kakadu National Park (Bayliss et al. 2006).

Common aquatic habitat types on the floodplain include paperbark (Melaleuca spp.) forests, open perennial and annual swamps, large perennial waterholes (ponds) and grass/sedge herbfields (Williams, 1979). Widespread grassland communities are dominated by: Hymenachne acutigluma (15\% of the floodplain), Pseudoraphis spinescens (14\%), and Oryza meridionalis (12\%) (Finlayson et al., 1993). Invasive para-grass (Urochloa mutica) has replaced large areas of native vegetation occupying $~ 35 \%$ of the floodplain (Bayliss et al., 2006).

Vegetation types and sampling

Sampling took place in areas dominated by particular aquatic plant species that represent the main structural life form types on the Magela floodplain (Fig. 1). We categorized aquatic macrophytes into four different structural and stem alignment groups based on the classification by Den Hartog and van der Velde (1988):

- Helophytes - Vertical emergent graminoids such as $H$. acutigluma, $O$. meriodalis, $U$. mutica, Leersia hexandra Sw., and Eleocharis dulcis (Burm.f.) Henschel. 
- Horizontal Helophytes - helophytes with horizontal stems growing just below the water surface, with only the terminal leaves and inflorescence emerging above the surface such as $P$. spinescens

- Nymphaeids - with attached floating leaves including Nymphaea violacea Lehm. and Nymphoidies indica (L.) Kuntze

- Ceratophyllids - submerged plants with whorls of leaves at each nodes such as Ceratophyllum demersum, Najas tenuifolia R.Br. and Utricularia aurea Lour.

For each aquatic macrophyte structural type, three replicate patches of approximately $400-$ $2500 \mathrm{~m}^{2}$ in area were sampled. Within each site three randomly chosen $1 \mathrm{~m}^{2}$ quadrats were placed and a visual estimate of plant cover was made for the quadrat and a sample of the aquatic macrophyte was taken. Samples of plant stems in the top $30 \mathrm{~cm}$ of the water column were collected so as not to disturb attached epiphytes and placed in buckets filled with water taken from the site. For each species, we cut sections of macrophyte leaves and stem (with the epiphytes attached to it) of approximately similar size and surface area. For each macrophyte sample we carefully removed attached epiphytes using a soft brush. Once removed, epiphytes were placed in zip-lock plastic bags and stored on ice for later measurement of biomass dry weight $(\mathrm{mg})$. Although the sampled epiphyte community includes, not only algae, but bacteria, protozoa, meiofauna, algae is generally the largest proportion of this community (Hutchinson 1975, Messasz et al., 2009). Macrophyte samples for each quadrat were also placed in zip-lock bags and stored on ice for later measurement of surface area $\left(\mathrm{m}^{2}\right)$ and dry weight $(\mathrm{g})$. Measurement of surface area was made directly for simple stems and for more complex shapes the macrophytes sample was placed on a herbarium sheet, pressed and dried and then scanned using an area meter (LiCor L3100C). Plants were sampled on consecutive days in April 2013. We also measured the emergent vertical macrophytes $L$. hexandra and $E$. dulcis and associated epiphytes on consecutive days 
in May 2013.

At each sample site we used a Licor light meter (Light Logger, Licor 1400 Spherical Sensor -

LI 193, measurements in $\mu$ mole $\sec ^{-1} \mathrm{~m}^{2}$ ) to take readings of ambient light just above and below the water surface and at $20 \mathrm{~cm}$ intervals through the water column until no light penetrated ( $0 \%$ of ambient) or when the bottom was reached. Light measurements through the water column were also converted to a light attenuation coefficient $(K d)$ (Colley-Davies and Nagels 2008) for each plant structural type. At each site, the physical and chemical characteristics of the water were determined through the water column using a multiparameter meter ('Hydrolab', QUANTA, ECO Environmental, Perth, Western Australia, Australia) for turbidity, $\mathrm{pH}$, temperature, dissolved oxygen and conductivity. Measurements were taken during the day between 10am and $3 \mathrm{pm}$. To gain a general impression of the dissolved nutrient status across the study area of the floodplain, we collected three replicate water samples at six sites at the top, middle and lower sections of the floodplain. Water samples were filtered on site, then stored on ice and transported to the laboratory to measure dissolved $\mathrm{N}\left(\mathrm{NO}_{x}\right.$ and $\left.\mathrm{NH}_{3}\right)$ and $\mathrm{P}\left(\mathrm{PO}_{4}{ }^{3-}\right)\left(\mathrm{mg} \mathrm{L}^{-1}\right)$.

Species Complexity Index (SCI)

A species complexity index ( $\mathrm{SCl}$ ) for each macrophyte species was calculated using the method of Dibble and Thomaz (2006) by measuring species-specific level of branching networks. For the macrophytes we sampled, three specimens of each species were mounted on herbarium sheets and positioned as best we could to mimic natural conditions. Specimens were pressed in a plant press taken back to laboratory for drying at $50^{\circ} \mathrm{C}$ for 24 
hours. On the dried specimens the number and width of interstices (open space between stems and leaves) were measured along the vertical and horizontal axes of the plant. A complexity index for each species was calculated as the sum of the mean number of interstices intercepted per meter divided by mean length $(\mathrm{cm})$ of interstices for each axis (i.e. $\mathrm{SCl}=($ frequency/length vertical axis $)+($ frequency/length horizontal axis $))$. This measure of species-specific structural complexity provides a relative measure of differences and similarities in the structural architecture of aquatic plants. The $\mathrm{SCl}$ provides a relative measure of complexity and is likely to be less accurate for plants with complex branching in three dimensions because we measured specimen interstices in only two dimensions. Therefore, this method is likely to underestimate actual complexity for some plant types (such as $C$. demersum).

Data analysis

All data were tested for normality and where appropriate log-transformed to linearize the relationship among variables and meet assumptions of normality using Primer-E software (Clarke and Gorley, 2006). When data did not meet normality requirements non parametric tests were used. Principal Components Analysis (PCA) was used (variables standardised) to assess differences in water physical and chemical properties (temperature, $\mathrm{pH}$, electrical conductivity, dissolved oxygen, turbidity and $\%$ of ambient light at $20 \mathrm{~cm}$ water depth) for the vegetation structural groups. Differences in water properties between plant structural types were also determined using analysis of variance (ANOVA), followed by Fisher's PLSD tests and Bonferroni correction. Relationships between species complexity index and epiphytic algae biomass were explored using Pearson correlation coefficients (Clarke and 
Gorley, 2006). Epiphyte and macrophyte biomass data were analysed using non-parametric routines in PRIMER Version 6.1.5 (Clarke and Gorley, 2006). A variation partitioning technique, distance-based (Euclidean) redundancy analysis (dbRDA), was performed using the DistLM and dbRDA routines in PERMANOVA+ (Legendre and Anderson, 1999) to explore which group of macrophytes and environmental variables best explained the spatial variation observed in epiphytic algae biomass per area and biomass of macrophyte. A BrayCurtis similarity matrix of the algal biomass for the different macrophyte types was used for this analysis, and a step-wise selection of the macrophyte structure and environmental variables (plant alignment (vertical or horizontal), $\mathrm{SCl}$, plant structural type and \% ambient light at $20 \mathrm{~cm}$ water depth) was conducted using the adjusted $\mathrm{R}^{2}$ selection criterion and a permutation test of significance (Legendre and Anderson, 1999). Ordination of macrophyte species assembles in dbRDA space also assisted in visualizing the effects of light and plant structural groups on epiphytic algae biomass.

\section{Results}

Water properties among macrophytes structural types

Differences in the water environment measured in different structural types (Table 1) indicated that electrical conductivity $(\mathrm{EC})$ was significantly different between plant types ( $\mathrm{F}=$ 9.13, $\mathrm{p}<0.001)$ with helophytes $($ EC $0.024 \mathrm{~ms} / \mathrm{cm})>$ nymphaeids $(0.019 \mathrm{~ms} / \mathrm{cm})=$ Open $(0.017 \mathrm{~ms} / \mathrm{cm})=$ ceratophyllid $(0.015 \mathrm{~ms} / \mathrm{cm})$. Dissolved oxygen (DO) was significantly higher $(F=23.7, p<0.001)$ in water at ceratophyllid patches $(D O, 6.03 \mathrm{mg} / \mathrm{L})>$ nymphaeids 
$(2.79 \mathrm{mg} / \mathrm{L})=$ Open $(2.16 \mathrm{mg} / \mathrm{L})>$ helophytes $(0.73 \mathrm{mg} / \mathrm{L})$. There was no difference between plant types in water temperature $(F=2.01, p=0.133), p H(F=5,08, p=0.06)$ or turbidity $(F$ $=4.1, p=0.048)$.

For all plant structural types water properties showed little difference with depth, suggesting mixing of the water column (Table 1). The exception was dissolved oxygen that showed lower values for all plant types at the greatest depth (1-1.5m), which was most pronounced in the dense emergent grass helophyte patches (Table 1). In particular the patches of the horizontal helophyte $P$. spinescens, with stems that lie across the water surface, showed the largest difference in DO with depth with high levels of DO at the surface but with very low levels at the bottom, under the dense mat of stems (Table 1). Dissolved nutrient levels were very low throughout the floodplain and showed no discernible trends between macrophytes types with $\mathrm{P}_{-} \mathrm{PO}_{4}$ ranging from below detection levels to $0.014 \mathrm{mgL}^{-1}$ and total dissolved $\mathrm{N}\left(\mathrm{NO}_{\mathrm{x}}+\mathrm{NH}_{3}\right) 0.01-0.17 \mathrm{mgL}^{-1}$.

Light attenuation coefficients through the water profile of the different macrophytes structural types showed the strong effect of differing plant cover (Table 1). The curve for the open water indicates clear water conditions with $10 \%$ of ambient light at a depth of 1.5m. Ambient light levels ranged across the sites and times from $1117-1431 \mu$ mole $^{-1}$ $\mathrm{m}^{2}$. Averaged values for plant structural types indicated the greater penetration of light in nymphaeids $(10 \%$ light at $80 \mathrm{~cm})$ and ceratophyllids $(10 \%$ at $55 \mathrm{~cm})$, compared with the helophytes $(10 \%$ at $28-45 \mathrm{~cm})$. For nymphaeids, because of their open structure and large gaps between leaves, there was low variability in measured light through the profile (CV at $20 \mathrm{~cm}=0.26$, at $100 \mathrm{~cm}=0.42$ ). For ceratophyllids, which formed floating mats at around 10 - 
$20 \mathrm{~cm}$ depth, there was little variation in light reading at $20 \mathrm{~cm}$ depth $(C V=0.24)$ but with high variability at $100 \mathrm{~cm}$ depth $(\mathrm{CV}=2.3)$. This is in contrast to helophytes where light attenuation was highly variable at $20 \mathrm{~cm}$ depth $(C V=1.47)$ but with low variability at $100 \mathrm{~cm}$ $(C V=0.15)$ as light is rapidly extinguished in the dense mats.

When all the measures of the water environment were combined in a PCA, we observed separation among the macrophyte vegetation types (Fig. 2), with greatest separation between ceratophyllids and helophytes. The separation between vegetation groups was mainly related to higher DO and lower conductivity in ceratophyllids compared to helophyte patches. The patches of different macrophyte types also showed a distinct temperature gradient along PCA axis 2 . The water characteristics for open water and nymphaeid plots were similar to each other and intermediate to the helophyte and ceratophyllid patches.

Epiphyte algae biomass among macrophytes structural types

The complexity of plant architecture varied considerably between the different aquatic plant types with helophytes having the simplest and the ceratophyllids the most complex structure (Fig. 3a). The biomass of epiphytes per area of macrophyte also varied in the same pattern. The ceratophyllids, with high complexity, had the highest epiphyte biomass and the helophytes the lowest (Fig. 3b). Macrophyte surface area or biomass were not good predictors of epiphyte biomass $(r=0.11, p>0.1 ; r=0.481 . p>0.1$, respectively, Fig.4c, $d)$. The species complexity index $(\mathrm{SCl})$ was a good indicator of the biomass of epiphytes on the different structural plant types for both per area and biomass of macrophytes (Fig. 4a, b). 
Plant alignment also influenced epiphyte biomass while other macrophyte features (e.g. plant structural type and area to weigh ratio of the macrophytes) did not have as strong an influence. This is highlighted in the multivariate analysis of how these variables affect epiphyte biomass with the DisLM analysis sequential tests indicating that $\mathrm{SCl}(\mathrm{F}=11.65, \mathrm{p}=$ $0.001)$ and plant alignment $(F=3.67, p=0.041)$ had the strongest influence on epiphytic biomass, with plant structural type $(F=0.31, p=0.89)$ and area/biomass $(F=0.49, p=0.74)$ not influential. This is graphically illustrated with epiphytes biomass on the different macrophyte types separated along the first dbRDA axis into ceratophyllid, nymphaeid and helophyte macrophytes (Fig. 5). The horizontal helophyte $P$. spinescens was an outlier in terms of emergent structural types and this is related to the horizontal alignment of this species (Fig. 5). The vector diagram indicates that in terms of epiphyte biomass, $\mathrm{SCl}$ and plant orientation had the strongest influence on the separation of macrophyte species.

\section{Discussion}

Importance of macrophytes architecture and alignment

Our study has shown that plant architecture is important for algal attachment on this tropical floodplain, with greater epiphyte biomass on macrophytes with high structural complexity. Aquatic plant morphologies also provide important habitat heterogeneity in aquatic systems (Dibble and Thomaz, 2006) and spatial complexity innate to the structural architecture of an individual plant creates diverse structures that enable maximum area for the attachment and access to sunlight for epiphytic algae (Taniguchi et al., 2003). 
The alignment of plant stems was also shown to be important, with stems aligned close to the horizontal plane allowing greater exposure to light for attached algae. In the aquatic phase the grass $P$. spinsescens has a simple architecture with horizontal stems growing just below the water surface, with only the terminal leaves and inflorescence emerging above the surface. This horizontal alignment presents a large surface area of the stem to sunlight and provides attachment sites conducive to high algae growth. This contrasts with other common aquatic macrophytes on the floodplain with emergent stems that grow vertically through and above the water column and have high stem density that create a highly shaded environment with greater light attenuation and higher conductivity, which together with their simple cylindrical stem structure, provide a less favourable environment for epiphytic algae. Our results agree with results found on the Parana River in South America where algal epiphyte biomass was lower where the vertically positioned emergent grass, Echinochloa polystactya (Kunth) Hitchc. was dense (Pizarro, 1999). In other studies, low algal epiphyte biomass was thought to be due to a combination of a low percentage of incident light and simple macrophyte stem types (McCormick et al., 1998; Gosselain et al., 2005). Our results further indicate that shape of the macrophyte and alignment, rather than surface area or plant biomass, result in greater epiphytic algae biomass attached to macrophytes. Therefore we suggest that the epiphytic algal biomass growing on macrophytes is mostly influenced by structural complexity and alignment of the macrophytes. Therefore complex architecture not only provides larger surface area than simple shapes, but also provides the greatest number of attachment sites that maximize access to light. For example the ceratophyllid $C$. demersum which have branched stems, with whorled leaves that are bifurcated and are further divided into serrated segments 
(Messasz et al., 2009) had the highest level of structural complexity and algal load in our study.

Effects of macrophytes on water conditions and light penetration

Our results show that particular water quality conditions are created by the different macrophyte vegetation types on the floodplain, likely influenced by their structure and density. Very different water characteristics were created in the dense helophytes compared with in the nymphaeid plants. In areas of low density macrophytes such as the beds of Nymphaea spp with large floating leaves, water quality conditions where similar to the open water areas. In contrast, dense emergent macrophytes can accumulate sediments and decomposing plant material, creating conditions of high electrical conductivity, high turbidity and low oxygen, which are generally unsuitable for fish, macroinvertebrates and algae. The position within macrophytes beds may also have a strong influence on the trapping of suspended matter and the establishment of epiphytes, with more suspended matter trapped along the edges than in the centre of the macrophytes bed (Vermaat et al., 2000).

Light attenuation by the macrophyte canopy can significantly alter the depth profile of photosynthesis in dense macrophyte stands (Adams et al., 1974). Photosynthesising submerged macrophytes themselves contribute to the high DO levels in the macrophyte patches (Pokorny and Rejmankova, 1983, Ondok et al., 1984) and we suggest that added to this the higher dissolved oxygen conditions that were characteristic of patches of $C$. demersum are related to a combination of greater light penetration for photosynthesis and 
the high periphyton biomass on this macrophyte. However increased epiphyte biomass can also result in higher light requirements for macrophytes (Dobberfuhl, 2007) so that the complex architecture with many different orientations of surfaces also allows better light penetration for photosynthesis. In contrast, dense emergent macrophytes with vertical stems prevent light penetration and their simple architecture provides little area that has good access to light for attachment of epiphytic algae (Pokorny and Rejmankova, 1983; Gosselain et al., 2005). Along with nutrients and herbivory, light availability is therefore a critical factor controlling periphyton biomass in low or non-flowing waterbodies such as the floodplain (Mosisch et al., 2001).

Increasing the area for primary production

For many aquatic environments, studies indicate the importance of the littoral zone for primary production (Winfield, 2004; Arrington and Winemiller, 2006; Strayer and Finlay, 2010). Shallow open littoral areas of the floodplain where light penetration is high and benthic algae can grow, results in high algal productivity and high DO levels during the day (Bunn et al., 2005; Strayer and Findlay, 2010). Our results indicate that the complex structured submerged ceratophyllids growing on the floodplain just below the water surface, such as $C$. demersum and $U$. aurea, effectively create a "false bottom" in the deeper waters of the floodplain. That is, these plants form a layer of submerged macrophyte 10-20 $\mathrm{cm}$ below the clear water surface, and function in a similar way to the littoral zone, except that because of their complex architecture they provide greater access to light and more sites for algal attachment than comparatively uniform benthic surfaces. This in effect greatly increases the area of the littoral zone, reaching all parts of the floodplain where 
these submerged plants occur. We suggest that this significantly boosts algal production within the flooded floodplain. This in-turn has implications for floodplain fish production that are dependent on algae as a basal food source (Hamilton et al., 1992; Jardine et al., 2012) and also as refuge areas of high DO during the day, in an otherwise low oxygen environment.

Other interactions between macrophytes and epiphytes

Other factors that may be at play in relation to higher epiphyte biomass on macrophytes with complex architecture include the interactions between macrophytes and animals, other plants, nutrients and water velocity. Higher epiphyte biomass on macrophytes with complex architecture may also be due to reduced grazing pressure as fish have often been shown to be less effective foragers in more complex habitats (Warfe and Barmuta, 2006). Complex architecture and high epiphyte biomass also creates diverse habitat and feeding opportunities for aquatic macroinvertebrates (Taniguchi et al., 2003). Allelopathy in macrophytes interfering with the settlement of epiphytic algae is thought to occur in most aquatic habitats (Gross, 2003). Although C. demersum has been shown to exhibit alleochemical compounds (Gross et al., 2003), in our study this species had the highest epiphytic algae biomass. In our case, production of ephiphytic algae is too high for any allelochemicals released to be effective, possibly because these chemicals are readily metabolized and need to be continuously released to reduce algal attachment to any great extent (Nakai et al., 1999). Epiphytic algal communities may also have been selected for their relative insensitivity to alleleopathic compounds (Wuim-Andersen 1987). 
Macrophytes may provide nutrients and carbon rather than just attachment sites for epiphytic algae as the accumulation of epiphytic algae is most evident in low nutrient conditions (Eminson and Moss, 1980), such as our sites. Photosynthesising macrophytes can also release up to $10 \%$ of their carbon as dissolved organic compounds (Wetzel, 1983), that can then be utilized by epiphytes. Although when macrophytes die and the decomposing material can release some $\mathrm{P}$, this may be insufficient to affect algae epiphyte growth (Carigan and Kalff, 1982). In our study, low dissolved nutrient levels but high algal biomass suggests that rapid recycling and uptake of nutrients is taking place (Cotner et al., 2006, Townsend et al., 2011). Spatial variability in nutrient concentrations between different macrophytes types may be small because any increase in nutrients is rapidly consumed by biota. For our study site, this is indicated by large and rapid reductions in dissolved nutrients levels between the inlet to the floodplain and the outlet $(40 \mathrm{~km}$ downstream) (Hart et al. 1987). Wet season higher temperatures and higher nutrient levels may also increase periphyton growth on macrophytes (dos Santos et al., 2013). Highly complex macrophyte structure may also reduce local water velocities, providing more protection against physical disturbance and therefore more epiphytic algal growth (Squires et al., 2009). Also in areas with high sedimentation such as littoral areas and backwaters, complex macrophytes will support higher epiphytic algae biomasses than benthic surfaces that can be affected by dense sediment cover (Gregg \& Rose, 1982).

\section{Management implications}

On the tropical floodplains of Kakadu NP several important management issues affect the distribution of the different vegetation patch types described in this study (Pettit et al., 2011). The biomass of epiphytic algae on the Magela floodplain has been estimated to be 
around $30 \%$ of macrophyte biomass (McBride, 1983) with biomass of emergent macrophytes making up around $26 \%$ of the area, while areas of submerged macrophytes make up around 4\% (Ward et al., 2014). Invasive para grass (Urochloa mutica) covers large areas of the floodplain and is spreading rapidly to the exclusion of other vegetation types (Ferdinands et al., 2005; Bayliss et al., 2012). The increase in this dense emergent, vertically aligned helophyte and the reduction of more open patches is likely to greatly inhibit epiphytic algae growth during periods of inundation and cause a shift in the structure of the floodplain food web, by reducing the food base for aquatic herbivores and increasing energy flow through detrital pathways. Dry season burning of the floodplain is an important management tool in Kakadu National Park (Bayliss et al., 2006) and in particular traditional indigenous patch-burning practices that create open areas on the floodplain. Open areas are likely created by fire in the dry season and are often colonized by complex submerged macrophytes communities such as $C$. demersum, $N$. tenuifolia and $U$. aurea during the flooded phase (Aaron Petty pers. comm.). This will enhance the number and extent of areas of relatively open patches of high algal production, thus increasing overall algal production on the floodplain, and in turn improve secondary production of fish, as they move onto the floodplain during the wet season (Jardine et al., 2012).

\section{Acknowledgements}

We thank Kakadu National Park staff, in particular Anne O’Dea for logistics and rangers

Calvin Murakami and Fred Hunter as our guides on the floodplains and keeping us safe and ERISS for providing accommodation in the Park. We thank Professor Bob Naiman for very 
constructive comments and discussion on earlier drafts and Dr Aaron Petty for help with

fieldwork and sharing his knowledge of the floodplain. This research was conducted with

the support of funding from the Australian Government's National Environmental Research

Program (NERP).

\section{References}

Adams, M.S., McCraken, M.D., 1974 Seasonal production of the Myriophyllum component of the littoral of Lake Wingra, Wisconsin. J Ecol. 62, 457-467.

Arrington, D.A., Winemiller, K.O., 2006 Habitat affinity, the seasonal flood pulse and community assembly in the littoral zone of a neotropical floodplain river. J N Am Benthol Soc, 25, 126-141.

Bayliss, P., van Dam, R., Boyden J., Walden D., 2006 Ecological risk assessment of Magela floodplain to differentiate mining and non-mining impacts. In: ERISS Research Summary 2004-2005 (Eds K.G. Evans, J. Rovis-Hermann , A. Webb \& D.R. Jones ), pp. 172-185. Supervising Scientist Report 189, Supervising Scientist, Darwin, NT, Australia.

Bayliss, P., van Dam, R., Bartolo, R., 2012 Quantitative ecological risk assessment of the Magela Creek floodplain in Kakadu National Park, Australia: comparing point source risks from the 508 Ranger uranium mine to diffuse landscape-scale risks. Hum Ecol Risk Assess, 18, 115-151.

Bunn, S.E., Balcombe, S.R., Davies, P.M., Fellows, C.S., McKenzie-Smith, F.J., 2005. Aquatic productivity and food webs of desert river ecosystems. In: Changeable, Changed, Changing: The Ecology of Desert Rivers (Ed. R. Kingsford), pp. 76-99. Cambridge University Press, Cambridge, UK.

Carignan, R., Kalff, J., 1982 Phosphorus release by submerged macrophytes: significance of epiphyton and phytoplankton. Limnol Oceanogr 27, 419-427.

Carpenter, S.R., Lodge D.M., 1986 Effects of submersed macrophytes on ecosystem processes. Aquatic Bot. 26, 341-370.

Clarke, K.R., Gorley, R.N., 2006 PRIMER v6: User Manual/Tutorial. Primer-E, Plymouth, UK.

Colley-Davies, R.J., Nagles, J.W. 2008 Predicting light penetration into river waters. J Geophys Res 113, G03028, doi: 10.1029/2008JG000722.

Cotner, J.B., Montoya, J.V., Roelke, D.L., Winemiller, K.O. 2006 Seasonally variable production in the Venezuelan Ilanos. J N Am Benthol Soc, 25, 171-184.

Davies, P.M., Bunn, S.E., Hamilton, S.K., 2008 Primary production in tropical streams and rivers. In: Tropical Stream Ecology (Ed. D. Dudgeon), Chapter 2, pp. 23-42, Elsevier, London, U.K.

Den Hartog, C., van der Velde, G., 1988. Structural aspects of aquatic plant communities. In: Symoens, J.J. (Ed.), Vegetation of Inland Waters. Handbook of Vegetation Science 15/1. Kluwer Academic Publishers, Dordrecht, pp. 113-153.

Dibble, E.D., Thomaz, S.M. 2006 A simple method to estimate spatial complexity in aquatic plants. Braz Arch Biol Techn, 49, 421-428. 
Dobberfuhl, D.R., 2007 Light limiting thresholds for submerged aquatic vegetation in a blackwater river. Aquatic Bot., 86, 346-352.

dos Santos, T.R., Ferragut, C., de Mattos Bicudo, C.E., 2013. Does macrophytes architecture influence periphyton? Relationships among Utricularia foliosa, periphyton assemblage structure and its nutrient (C, N, P) status. Hydrobiologia, 714, 71-83.

Eminson, D., Moss, B., 1980. The composition and ecology of periphyton communities in freshwaters. 1. The influence of host type and external environment on community composition. Brit Phycol J, 15, 429-446.

Ferdinands, K., Beggs, K., Whitehead P., 2005 Biodiversity and invasive grass species: multiple-use or monoculture? Wildlife Res, 32, 447-457.

Finlayson, C.M., 2005 Plant ecology of Australia's tropical floodplain wetlands: a review. Ann Bot, 96, 541-555.

Finlayson, C.M., Cowie, I.D., Bailey, B.J., 1990 Characteristics of a seasonally flooded freshwater system in monsoonal Australia. In: Wetland Ecology and Management: Case Studies (Eds D.F. Whigham , R.E. Good \& J. Kvet ), pp. 141-162. Kluwer Academic Publishers, Dordrecht, Netherlands.

Finlayson, C.M., Cowie, I.D., Bailey, B.J., 1993 Biomass and litter dynamics in a Melaleuca forest on a seasonally inundated floodplain in tropical, northern Australia. Wetl Ecol Manag, 2, 177-188.

Gentilli, J., 1972 Australian Climate Patterns. Thomas Nelson Limited, Melbourne, Australia.

Gosselain, V., Hudon, C., Cattaneo, A., Gagnon, P., Planas, D., Rochefort, D., 2005 Physical variables driving epiphytic algal biomass in dense macrophytes beds of the St Lawrence River (Quebec, Canada). Hydrobiologia, 534, 11-22.

Gregg, W.W., Rose, F.L., 1982. The effects of aquatic macrophytes on the stream microenvironment. Aquatic Bot, 14, 309-324.

Gross, E.M., 2003 Allelopathy of aquatic autotrophs. Crit Rev Plant Sci, 22, 313-339.

Gross, E.M., Erhard, D., Ivanyi, E., 2003 Allelopathic activity of Ceratophyllum demersum L. and Najas marina ssp. intermedia (Wolfgang) Casper. Hydrobiologia 506-509, 583-589.

Hamilton, S.K., Lewis, W.M., Sippel, S.J., 1992 Energy sources for aquatic animals in the Orinoco River floodplain: evidence from stable isotopes. Oecologia, 89, 324-330.

Hart, B.T., Ottaway, E.M., Noller, B.N., 1987 Magela Creek system, northern Australia II. Material budget for the floodplain. Aust J Mar Fresh Res, 38, 861-876.

Hinojosa-Garro, D., Mason, C.F., Underwood, G.J.C., 2010 Influence of macrophytes spatial architecture on periphyton and macrophytes community structure in shallow water bodies under contrasting land management. Fund Appl Limnol 177, 19-37.

Hutchinson, G.E., 1975 A Treatise on Limnology Vol III. Limnological Botany, Wiley, New York, USA.

Jardine, T.D., Pusey, B.J., Hamilton, S.K., Pettit, N.E., Davies, P.M., Douglas, M.M., Sinnamon, V., Halliday, I.A., Bunn, S.E., 2012 Fish mediate high food web connectivity in the lower reaches of a tropical floodplain river. Oecologia 168, 829-838.

Jones, J.I., Moss, B., Eaton, J.W., Young, J.O., 2000 Do submerged aquatic plants influence periphyton community composition for the benefit of invertebrate mutualists? Freshwater Biol. 43, 591-604.

Junk, W.J., Piedade, M.T., 1997 Plant life in the floodplain with special reference to herbaceous plants. In: The Central Amazon Basin: Ecology of a Pulsing Basin (ed. W.J. Junk). pp. 147-185. Springer, Berlin, Germany. 
Junk, W.J., Wantzen, K.M., 2004 The flood pulse concept: new aspects, approaches and applications - an update. In: 2nd International Symposium on the Management of Large Rivers for Fisheries (Eds R.L. Welcomme \& T. Petr ), pp. 117-140. FAO \& Mekong River Commission, Bangkok, Thailand.

Keizer, F.M., Schot, P.P., Okruszko, T., Chormanski, J., Kardel, I., Wassen, M.J., 2014. A new look at the flood pulse concept: The (ir)relevance of the moving littoral in temperate zone rivers. Ecol Eng 64, 85-99.

Legendre, P., Anderson, M.J., 1999. Distance-based redundancy analysis: testing multispecies responses in multifactorial ecological experiments. Ecol Monogr 69, 1-24.

Lewis, W.M., Hamilton, S.K., Rodriguez, M.A., Saunders, J.F., Lasi, M.A., 2001. Foodweb analysis of the Orinoco floodplain based on production estimates and stable isotope data. J N Am Benthol Soc, 20, 241-254.

McBride, P. 1983. Diatom communities of the Mudginberri Corridor, Northern Territory, Australia: Their structure, annual succession, and responses to environmental change. PhD Thesis, Macquarie University, Sydney, Australia.

McClain, M.E., Richey, J.E., 1996. Regional-scale linkages of terrestrial and lotic ecosystems in the Amazon basin: a conceptual model for organic matter. Archiv Fur Hydrobiolgie Suppl, 113, 111-125.

McCormick, P.V., Shuford, R.B.E., Backus, J.G., Kennedy, W.C., 1998. Spatial and seasonal patterns of periphyton biomass and productivity in the northern Everglades, Florida, USA. Hydrobiologia, 362, 185-208.

Messasz, B., Kuczynska, N., Nagengast, B., 2009. The epiphyte communities of various ecological types of aquatic vegetation of five pastoral ponds. Biologia, 64, 88-96.

Mosisch, T.D., Bunn, S.E., Davies, P.M., 2001. The relative importance of shading and nutrients on algal production in subtropical streams. Freshwater Biol, 46, 1269-1278.

Nakai, S., Inoue, Y., Hosomi, M., Murakami, A., 1999. Growth inhibition of blue-green algae by allelopathic effects of macrophyte, Water Sci. Technol, 39, 47-53.

Ondok, J.P., Pokorny, J., Kvet, J., 1984. Model of diurnal fluctuations of oxygen, carbon dioxide and bicarbonate concentrations in a stand of Elodea canadensis Michx. Aquat Bot 19, 293-305.

Pettit, N.E., Bayliss, P., Davies, P.M., Hamilton, S.K., Warfe, D.M., Bunn, S.E., Douglas, M.M., 2011. Seasonal contrasts in carbon resources and ecological processes on a tropical floodplain. Freshwater Biol 56: 1047-1064.

Piedade, M.T.F., Junk, W.J., Long, S.P., 1991. The productivity of the $C_{4}$ grass Echinochloa polystachya on the Amazon floodplain. Ecology, 72, 1456-1463.

Pizarro, H. 1999. Periphyton biomass on Enchinochloa polystachya (H.B.K.) Hitch. Of a lake of the lower Parana River floodplain, Argentina. Hydrobiologia 397, 227-239.

Pokorny, J., Rejmankova, E., 1983. Oxygen regime in a fish pond with duckweed (Lemnaceae) and Ceratophyllum. Aquat. Bot. 17, 123-137.

Silva, T.S.F., Costa, M.M., Melack, J.M., 2009. Annual net primary productivity of macrophytes in the Eastern Amazon floodplain. Wetlands 29 (2), 747-758.

Squires, M.M., Lesack, L.F., Hecky, R.E., Guildford, S.J., Ramlal, P. and Higgins, S.N., 2009 Primary production and carbon dioxide metabolic balance of a lake-rich artic river floodplain: Partioning of phytoplankton, epipelon, macrophytes and epiphyton production among lakes on the Mackenzie delta. Ecosystems, 12, 853-872.

Strayer, D.L., Findlay, S.E.G., 2010 Ecology of freshwater shore zones. Aquat Sci, 72, 127163. 
Taniguchi, H., Nakano, S., Tokeshi, M., 2003. Influences of habitat complexity on the diversity and abundance of epiphytic invertebrates on plants. Freshwater Biol, 48, 718728.

Townsend, S.A., Webster, I.T., Schult, J.H. 2011 Metabolism in a groundwater-fed river system in the Australian wet/dry tropics: tight coupling of photosynthesis and respiration. J N Am Benthol Soc, 30, 603-620.

Vermaat J.E., Santamaria L. \& Roos P.J., 2000. Water flow across and sediment trapping in submerged macrophyte beds of contrasting growth form. Arch. Hydrobiol. 148: 549-562.

Ward, D.P., Petty, A., Setterfield, S.A., Douglas, M.M., Ferdinands, K., Hamilton, S.K., Phinn, S., 2014. Floodplain inundation and vegetation dynamics in the Alligator Rivers region (Kakadu) of northern Australia assessed using optical and radar remote sensing. Remote Sens Environ, 147, 43-55.

Warfe, D.M., Barmuta L.A. 2006. Habitat structural complexity mediates food web dynamics in a freshwater macrophyte community. Oecologia, 150, 141-154.

Wetzel, R. G., 1983. Limnology. Saunders College Publishing, Philadelphia.

Whitehead, P.J., McGuffog, T., 1997. Fire and vegetation pattern in a tropical floodplain grassland: a description from the Mary River floodplain. Biol Cons, 52, 58-111.

Williams, A.R., 1979. Vegetation and stream pattern as indicators of water movement on the Magela floodplain, Northern Territory. Aust J Ecol, 4, 239-247.

Winemiller, K.O., 2004. Floodplain river food webs: Generalisations and implications for fisheries management. In: 2nd International Symposium on the Management of Large Rivers for Fisheries (Eds R.L. Welcomme \& T. Petr), pp. 287-309. FAO \& Mekong River Commission, Bangkok, Thailand.

Winfield, I.J., 2004. Fish in the littoral zone: ecology, threats and management. Limnologica, 34, 124-131.

Wuim-Andersen, S. (1987) Allelopathy among aquatic plants Arch Hydrobiol Beih Erg Limnol $27,167-172$. 
Table 1. Mean $( \pm S E)$ water quality, vegetation cover for 3 replicates $1 \mathrm{~m} 2$ quadrats at 3 sites for each vegetation type and open water at three depths on the Magela $\mathrm{Ck}$ floodplain.

\begin{tabular}{|c|c|c|c|c|c|c|c|}
\hline $\begin{array}{l}\text { Water } \\
\text { depth } \\
\text { (cm) }\end{array}$ & $\begin{array}{l}\text { Vegetation } \\
\text { Cover } \%\end{array}$ & Temp. $\left({ }^{\circ} \mathrm{C}\right)$ & $\mathrm{EC}(\mu \mathrm{S} / \mathrm{cm})$ & $\begin{array}{l}\text { DO } \\
(\mathrm{mg} / \mathrm{L})\end{array}$ & $\mathrm{pH}$ & $\begin{array}{l}\text { Turbidity } \\
\text { (NTU) }\end{array}$ & $\mathrm{Kd}^{*}$ \\
\hline & \multicolumn{7}{|l|}{ Open Water } \\
\hline 20 & 0 & $32.4 \pm 0.6$ & $17 \pm 0.7$ & $2.7 \pm 0.8$ & $5.5 \pm 0.1$ & $1.7 \pm 0.1$ & $1.7 \pm 0.2$ \\
\hline 70 & & $31.8 \pm 0.3$ & $17 \pm 0.8$ & $2.5 \pm 0.8$ & $5.2 \pm 0.1$ & & \\
\hline \multirow[t]{2}{*}{120} & & $31.3 \pm 0.1$ & $18 \pm 0.8$ & $1.3 \pm 0.5$ & $5.1 \pm 0.1$ & & \\
\hline & \multicolumn{7}{|c|}{ Nymphaea violaea } \\
\hline 20 & 64.5 & $32.7 \pm 0.5$ & $19 \pm 1$ & $3.1 \pm 1.6$ & $5.3 \pm 0.1$ & $3.3 \pm 0.9$ & $3.4 \pm 0.1$ \\
\hline 70 & & $32.2 \pm 0.4$ & $19 \pm 1.2$ & $2.8 \pm 1.4$ & $5.1 \pm 0.1$ & & \\
\hline \multirow[t]{2}{*}{120} & & $31.7 \pm 0.1$ & $19 \pm 1.2$ & $2.4 \pm 1.1$ & $5.0 \pm 0.0$ & & \\
\hline & \multicolumn{7}{|c|}{ Ceratophyllum demersum } \\
\hline 20 & 95.8 & $31.8 \pm 0.7$ & $15 \pm 0.0$ & $6.8 \pm 0.6$ & $5.6 \pm 0.1$ & $2.0 \pm 0.5$ & $6.3 \pm 0.5$ \\
\hline 70 & & $31.2 \pm 0.7$ & $15 \pm 0.2$ & $6.3 \pm 0.8$ & $5.5 \pm 0.2$ & & \\
\hline \multirow[t]{2}{*}{120} & & $30.5 \pm 0.2$ & $16 \pm 0.3$ & $5.0 \pm 1$ & $5.4 \pm 0.2$ & & \\
\hline & \multicolumn{7}{|c|}{ Hymenachne acutigluma } \\
\hline 20 & 77 & $32.6 \pm 0.8$ & $32 \pm 2$ & $0.5 \pm 0.3$ & $5.3 \pm 0.1$ & $5.10 \pm 3$ & $7.6 \pm 1$ \\
\hline 70 & & $32.3 \pm 0.4$ & $33 \pm 1$ & $0.2 \pm 0.4$ & $5.1 \pm 0.1$ & & \\
\hline \multirow[t]{2}{*}{120} & & $32.1 \pm 0.4$ & $34 \pm 1$ & $0.2 \pm 0.1$ & $5.1 \pm 0.1$ & & \\
\hline & \multicolumn{7}{|c|}{ Urochloa mutica } \\
\hline 20 & 64.6 & $33.8 \pm 0.7$ & $20 \pm 0.7$ & $1.6 \pm 0.7$ & $5.4 \pm 0.2$ & $6.52 \pm 2.4$ & $8.5 \pm 0.6$ \\
\hline 70 & & $32.0 \pm 0.4$ & $18 \pm 0.9$ & $1.5 \pm 0.8$ & $5.3 \pm 0.1$ & & \\
\hline \multirow[t]{2}{*}{120} & & $31.1 \pm 0.3$ & $24 \pm 1$ & $0.3 \pm 0.3$ & $5.1 \pm 0.1$ & & \\
\hline & \multicolumn{7}{|c|}{ Psuedoraphis spinescens } \\
\hline 20 & 85.4 & $32.3 \pm 0.5$ & $16 \pm 0.8$ & $5.1 \pm 1.5$ & $5.5 \pm 0.2$ & $4.5 \pm 0.6$ & $6.4 \pm 0.8$ \\
\hline 70 & & $31.5 \pm 0.4$ & $17 \pm 1$ & $0.8 \pm 0.6$ & $5.1 \pm 0.2$ & & \\
\hline \multirow[t]{2}{*}{120} & & $30.5 \pm 0.2$ & $18 \pm 0.9$ & $0.3 \pm 0.3$ & $4.9 \pm 0.1$ & & \\
\hline & \multicolumn{7}{|c|}{ Oryza meriodalis } \\
\hline 20 & 88 & $31.0 \pm 0.8$ & $19 \pm 0.9$ & $1.17 \pm 0.8$ & $5.1 \pm 0.2$ & $15.3 \pm 7.2$ & $12.8 \pm 1$ \\
\hline 70 & & $30.9 \pm 0.4$ & $20 \pm 2$ & $0.68 \pm 0.4$ & $4.9 \pm 0.1$ & & \\
\hline 120 & & $30.8 \pm 0.3$ & $20 \pm 1$ & $0.3 \pm 0.1$ & $4.9 \pm 0.1$ & & \\
\hline
\end{tabular}

*light attenuation coefficient 

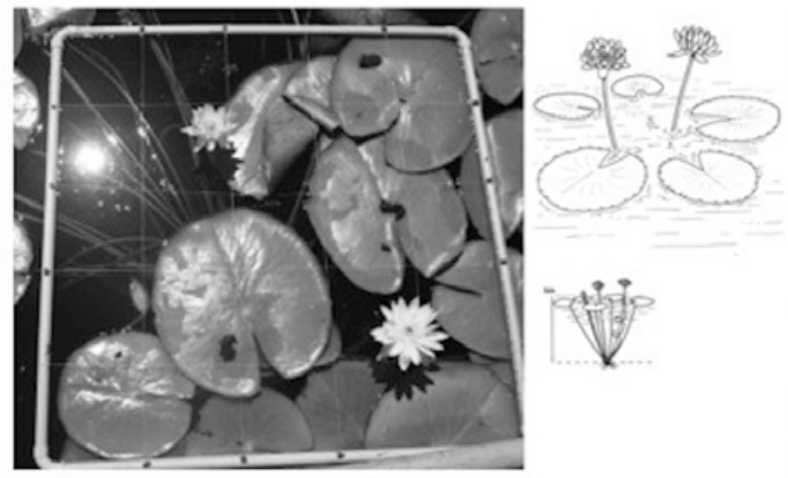

a) Nymphaeid - Nymphaea violacea
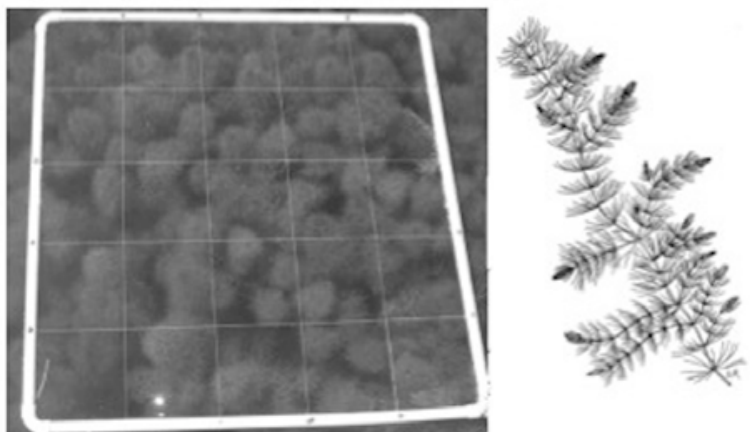

b) Ceratophyllid - Ceratophyllum demersum

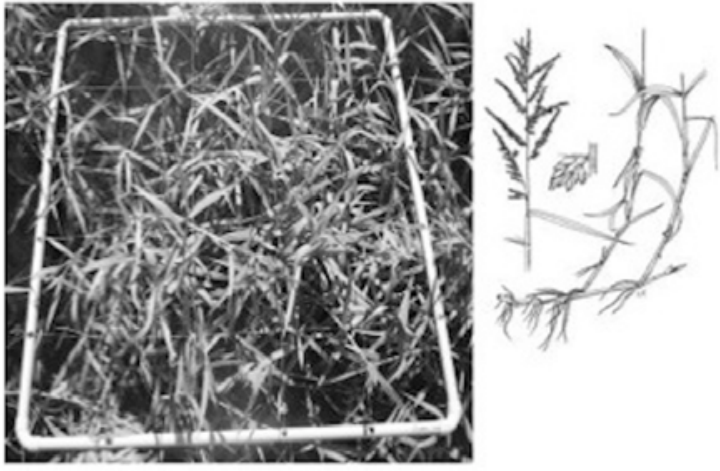

c) Helophyte - Urochloa mutica

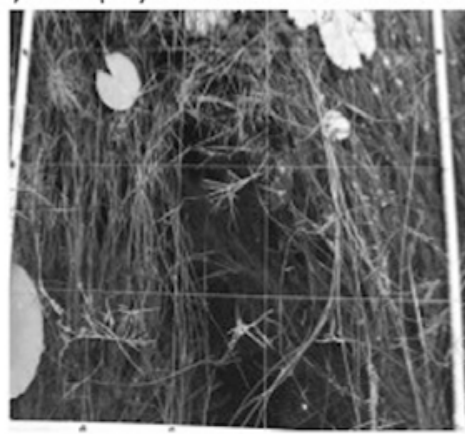

d) Horizontal Helophyte - Psuedoraphis spinescens

Figure 1. Species representing four of the main structural life form types of aquatic macrophytes found on the Magela Ck floodplain. 


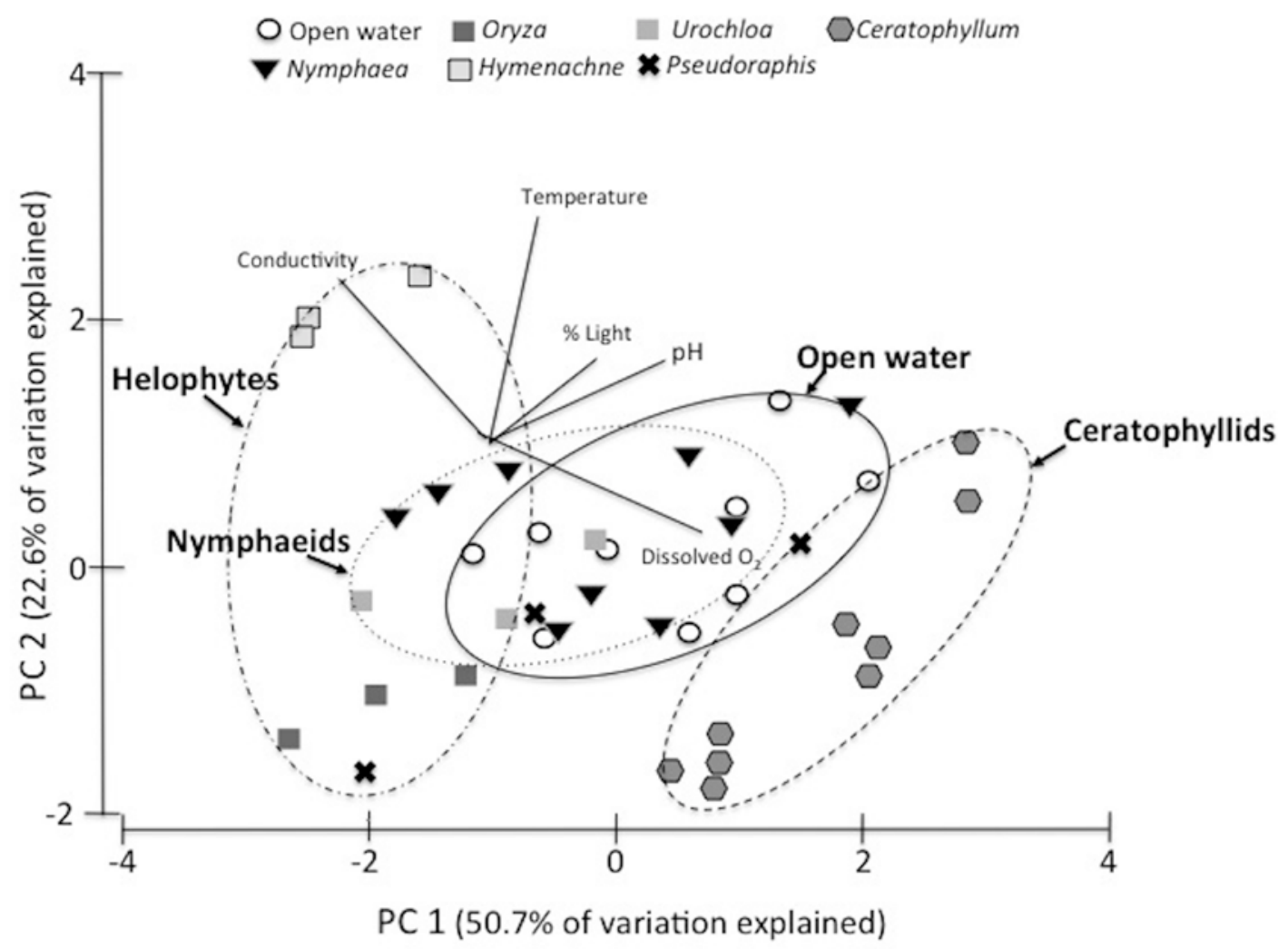

Figure 2. PCA ordination of the water quality differences in the different vegetation structural groups (eclipses) and species plots (symbols). Vector diagram indicating the strength and influence of individual measured water parameters on PCA axes and therefore grouping of different sites $(r>0.4)$. 

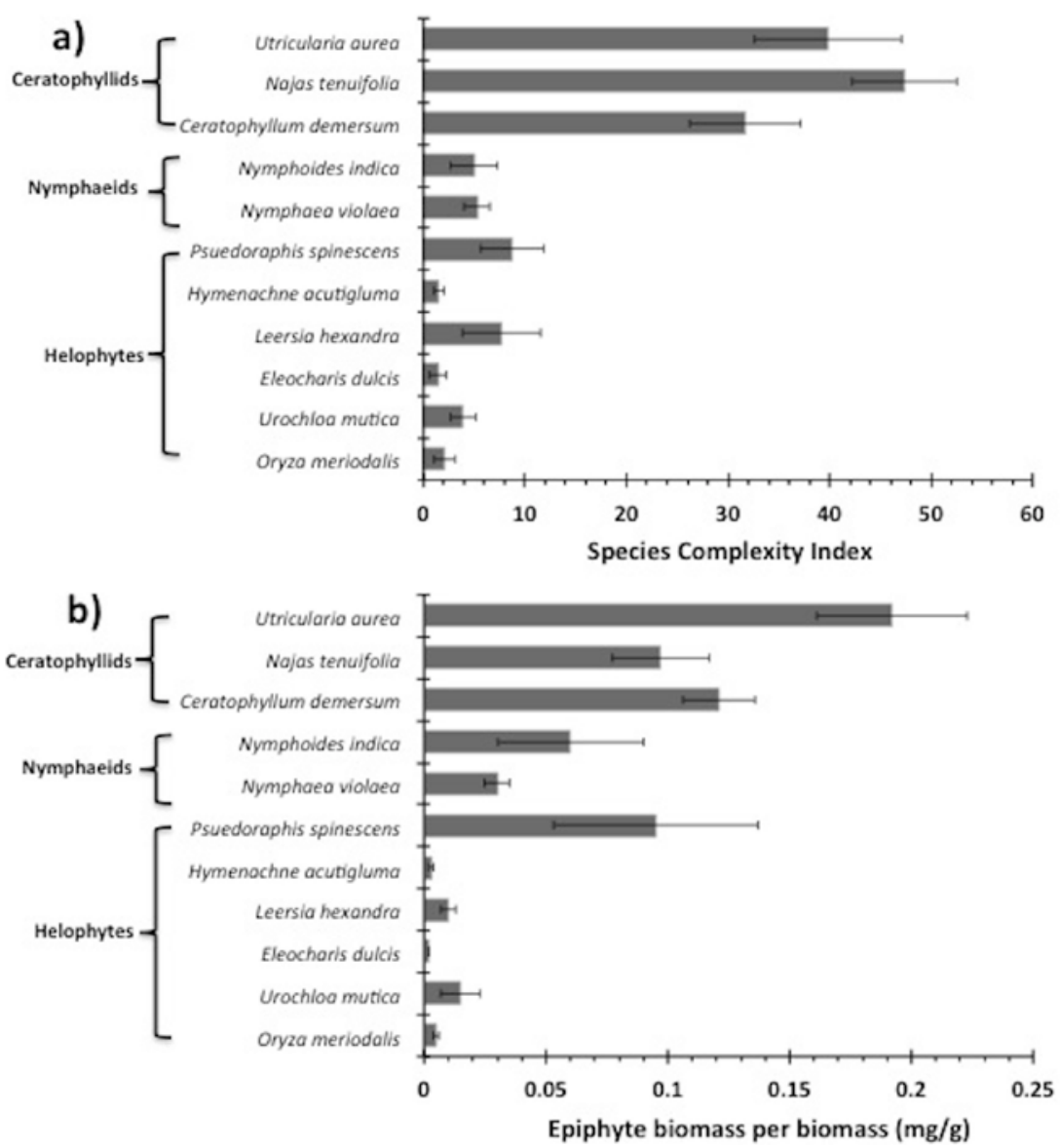

Figure 3. (a) Species complexity index ( $\mathrm{SCl}$ ) of macrophyte species. (b) Algal epiphyte biomass for the different macrophyte species and growth form. 

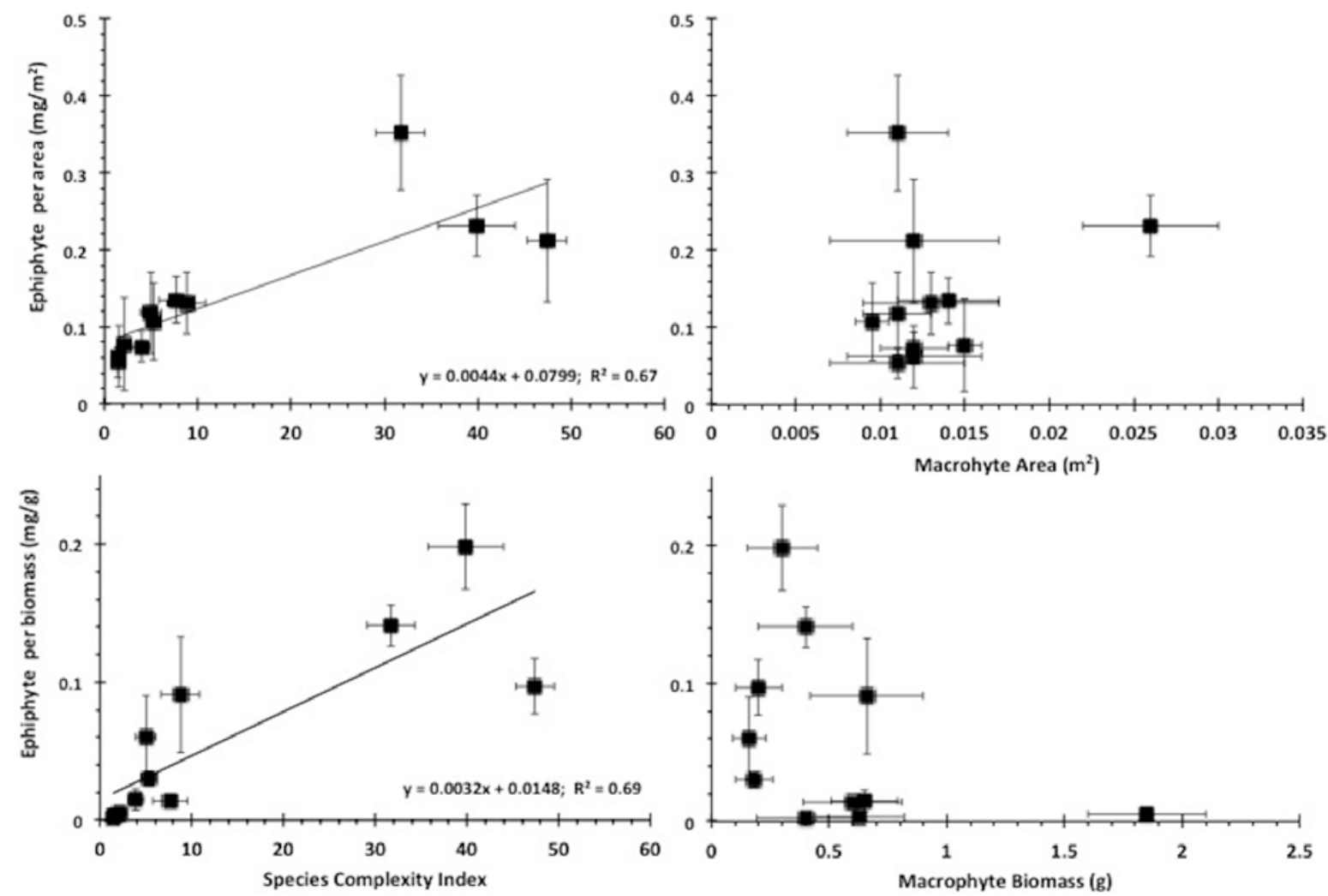

Figure 4. The relationship between species complexity index and (a) algae epiphyte biomass per macrophyte surface area $(0.1<p<0.05)$ and $(b)$ algae epiphyte biomass per macrophyte biomass $(0.05<p<0.01)$ and relationship between epiphyte biomass and $(c)$ macrophyte surface area ( $p>0.1)$ and (d) macrophyte biomass $(p>0.1)$ of the different macrophyte species. 


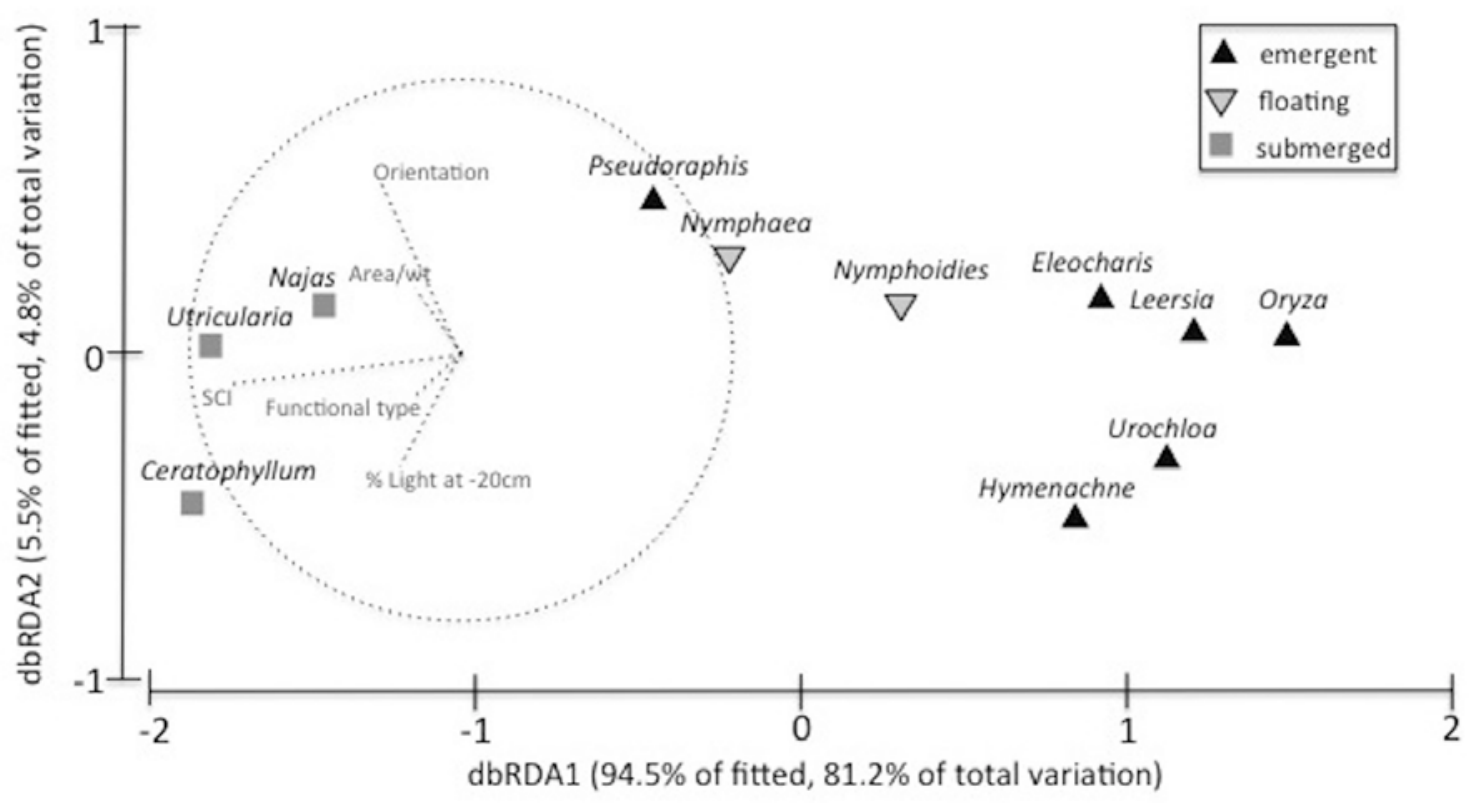

Figure 5. dbRDA of biomass of algae attached to macrophyte species representative of the difference in macrophyte structural types. Including nymphaeids (Nymphaea violocaea, Nymphodies indica), ceratophyllids (Ceratophyllum demersum, Najas tenuifolia, Utricularia aurea), helophyte-horizontal (Psuedoraphis spinescens) and helophyte-vertical (Oryza meriodalis, Urochloa mutica, Eleocharis dulcis, Leersia hexandra, Hymenachne acutigluma). Vector diagram indicates the influence of functional traits of macrophytes on epiphyte production with species complexity index $(\mathrm{SCl})$ and plant orientation having the strongest influence on the separation of species. 